\title{
The Erosion of the German System of Industrial Relations
}

\section{Anke Hassel}

\section{Article by an MPIfG researcher}

Anke Hassel: The Erosion of the German System of Industrial Relations. In: British Journal of Industrial Relations 37(3), 483-505 (1999). Wiley-Blackwell

The original publication is available at the publisher's web site: http://dx.doi.org/10.1111/1467-8543.00138

\begin{abstract}
The paper assesses current trajectories of change in the German system of industrial relations by analysing the co-determination and collective bargaining systems. It argues that two parallel developments undermine the institutional stability of the German model. First, the institutional base of the German industrial relations system, which has served as the precondition of its past success, has been shrinking during the last two decades. This is due to a decline in coverage by the two major industrial relations institutions: the works council system and wage agreements. Today fewer than 15 per cent of German plants are covered by both a valid collective agreement and a works council. Second, increasing decentralization pressures within collective bargaining tend to undermine the division of labour between co-determination and collective bargaining. The dynamics of an institutional erosion of the German industrial relations institutions and the decentralization of collective bargaining disturbs the fine-tuning of the mediating process between macroeconomic steering capacity and co-operative workplace industrial relations. This tendency has been aggravated by the effects of German unification. The current institutional developments of the German industrial relations system leave serious doubts about the future of a successful model of co-operative modernization.
\end{abstract}

\section{Introduction}

Until the early 1990s, the German model of industrial relations impressed many observers by its robustness, its potential for providing social cohesion, its business competitiveness, a low record of industrial disputes and a high level of training. The German model was based on a complex and differentiated structure of institutions which were mutually supportive and functionally beneficial for all actors of the economy (Hassel and Schulten 1998). At the centre of these institutions were the central wage agreements. These protected large numbers of employees from rough

Anke Hassel is at the Max Planck Institute for the Study of Societies in Cologne. 
labour market conditions, and created homogeneous conditions for companies by taking the price for the factor labour out of competition on the labour market and thereby providing comparable labour costs for all companies. ${ }^{1}$ They enabled industrial order and secure planning. On the whole, the system of central collective agreements was aimed at a high degree of consensus and co-operation and has helped to make the production factor 'social peace' a trademark of German capitalism.

Unlike many European economies, the German system of centralized wage bargaining did not suffer from the trend towards decentralization during the 1980s. At the time it was argued that the interaction with plantlevel co-determination committees enabled a flexible implementation of collective agreements and a constant flow of information between the companies and the collective bargaining actors. In the 1980s it seemed that the close relationship between works councils and trade unions had become more important:

The crisis of Keynesianism and the restructuring of production now underway throughout the advanced industrial world have forced a shift away from the dominance of quantitative (wage) issues towards qualitative issues such as skills and work organization. This shift has involved a partial decentralization of bargaining, because such qualitative issues are often plant-specific and thus difficult to resolve in the context of uniform centralized negotiations. Hence plant-level bargaining has grown more important in part because of the very nature of the challenges labor now faces. The dual system, combining as it does strong centralized co-ordination with substantial decentralized labour powers, has given German union strategic flexibility to meet these new challenges. (Thelen 1991: 3)

Today, at the end of the 1990s, in spite of the virtues of the German model, the pressures on the system to change are overwhelming. Employers are increasingly resigning from employers' confederations or are undercutting — often illegally — terms and conditions provided by collective agreements. Trade union strength is declining rapidly. The coverage of collective agreements is shrinking and the heterogeneity of labour market conditions is increasing. Vocational training is in a severe crisis because of the reluctance of companies to take on trainees. It seems that an economically highly successful model which enabled a functional integration of social justice and economic competitiveness is coming to the verge of imminent fundamental change.

The aim of the paper is to analyse the current trajectories of change in the German system of industrial relations. It analyses the two main pillars of the German dual system - the co-determination and collective bargaining systems - and assesses ongoing trends. It argues that two parallel developments undermine the institutional stability of the German model. First, the institutional base of the German industrial relations system, which has served as the pre-condition of its past success, has not been able to transfer its institutions beyond manufacturing industries into emerging 
areas of economic growth. Because of this lack of adjustment to new labour market developments as well as new forms of company structure, collective actors have lost their capacity for regulating employment conditions. Second, changing employment structures and decentralization pressures within collective bargaining blur the division of labour between codetermination and collective bargaining. Increasing decentralization without guidance by collective agreements disturbs the fine-tuning of the mediating process between macroeconomic steering capacity and cooperative workplace industrial relations. Aggravated by the effects of German unification on the German industrial relations system, the current institutional developments of the German system leave serious doubts about the future of a successful model of co-operative modernization.

\section{Co-determination and collective bargaining}

The German dual system of industrial relations has gained a unique status in international comparative studies because of the level of exclusiveness of the two pillars of interest representation. ${ }^{2}$ While other European countries, e.g. Belgium, Austria, Sweden, Denmark and the Netherlands, also have a two-layer system with collective bargaining on the one hand and plant-level works councils on the other, these two layers often overlap (Thelen and Turner 1997). In Germany, however, both layers are clearly divided into (a) the role of moderating distributional conflict between trade unions and employers' confederations and (b) overseeing plant-level consultation. This arrangement of complementing institutions applies to the actors, the form of interest representation, their range of action and the content of regulation (see Table 1).

TABLE 1

Collective Bargaining and Co-determination in the German System of Industrial Relations

\begin{tabular}{|c|c|c|}
\hline & Collective bargaining & Co-determination \\
\hline $\begin{array}{l}\text { Form of interest } \\
\text { organization }\end{array}$ & $\begin{array}{l}\text { Voluntary membership in } \\
\text { associations }\end{array}$ & $\begin{array}{l}\text { Election of legally based } \\
\text { bodies }\end{array}$ \\
\hline Actors & $\begin{array}{l}\text { Trade unions and employers' } \\
\text { associations }\end{array}$ & Works councils \\
\hline Range of action & $\begin{array}{l}\text { Bargaining } \\
\text { Industrial disputes }\end{array}$ & $\begin{array}{l}\text { Consultation } \\
\text { Package deals }\end{array}$ \\
\hline Content of regulation & $\begin{array}{l}\text { Substantial aspects of the } \\
\text { employment contract, procedural } \\
\text { aspects, joint bodies }\end{array}$ & $\begin{array}{l}\text { Individual grievances, } \\
\text { implementation of } \\
\text { collective agreements. }\end{array}$ \\
\hline
\end{tabular}

The organization of interests in both pillars is arranged in fundamentally different ways. Co-determination is carried out through a legally based elected body of all employees which can represent the plant-specific 
interests of employees in a legally defined way. Collective bargaining, on the other hand, is based on trade unions and employers' confederations which are free to participate. The relationship between co-determination and collective bargaining is a complementary one since there are no overlapping decision-making rights between the two pillars. Works councils can conclude plant agreements with local management on issues that are not, or usually not, covered by collective agreements. The only exception to this rule is when collective agreements deliberately delegate issues to be dealt with at the plant level (Section 77 III Works Constitution Act Betriebsverfassungsgesetz).

This does not, however, mean that works councils have never been involved in wage bargaining. Central and uniform agreements covering several million employees and different industrial branches do not allow for specific needs of companies and branches. Employers are expected to meet high standards in order to pay high wages. High performing companies are in a good position to do that, but others are not. Voluntary bonuses and pay above the going rate were the means of differentiating between high performing and low performing companies. In German manufacturing industries there has been an average wage drift between the collectively agreed wage and the effective wage of between 8 and 12 per cent (Schnabel 1994). ${ }^{3}$

This wage drift was traditionally part of the local bargaining between works council and local management. Big car manufacturers, for example, not only were paying 'above the going rate' (über Tarif), but also had a range of special provisions for their work-forces such as special bonuses, special holidays for family reasons and special allowances for housing. For the employers, it was a certain element of the prerogative of management that they could unilaterally decide on wage developments in the industry and have a bargaining offer vis- $a$-vis the works council.

For the German trade unions also, the informal and often secret nature of local wage bargaining was a way of building a bridge between the political aim of a solidaristic wage policy and the real differences between companies in their capacity to afford certain wage levels. While unions officially rejected wage differentials and demanded the same wage for the same job, the ability of big companies to pay was always a factor in wage bargaining (Streeck 1984a: 159).

Plant-level co-determination also enables managements to integrate employees' interests and demands into their corporate governance style, since the relationship between works councils and management was cooperative both by law and by nature. Since collective bargaining takes on the distributive function and thereby confines the conflict between capital and labour to that level, there was no direct need not to recognize legitimate employees' concerns in the personnel policy of management (Streeck 1984b).

The clear division of labour within the relationship between collective bargaining and co-determination depends on two factors. The first is the 
law that gives collective bargaining a higher status than co-determination and provides strict rules on the interplay between the two pillars. In particular, the ban on collective bargaining for works councils is a strong institutional barrier for a further decentralization of German industrial relations. The second, and more important, factor is the 'encompassing character' of the German trade union system. Industrial trade unionism enabled a monopoly of interest representation and prevented competition between trade unions. Small and particularistic trade unions did not have access to the collective bargaining cartels between the trade unions of the German trade union confederation - Deutscher Gewerkschaftsbund (DGB) - and the employers' confederations. Their monopoly position has been secured by works councils which were made up of DGB members and which ensured membership recruitment within the DGB. At the same time, works councillors were the main actors in trade union collective bargaining committees and guaranteed that trade union policy was in line with current economic problems in manufacturing companies of the private sector.

Co-determination and collective bargaining therefore reached a degree of complementarity that goes far beyond a simple division of labour between the bargaining over agreements by the trade unions and the implementation of agreements by the works councils. The linkages between the two are of a systemic as well as a functional nature. Encompassing trade unions and employers' confederations, a high degree of jurisdiction and a clear division of responsibility, tasks and representation capacity can support and reproduce each other. A shift in the balance between the two pillars and a transfer of functions from one to the other therefore has major repercussions for the whole system.

\section{The decline in coverage by industrial relations institutions}

During the last two decades, both the system of plant-level co-determination and the system of collective bargaining have lost ground in terms of coverage. In 1997, only 14.4 per cent of West German and 12.3 per cent of East German plants were covered by a valid collective agreement as well as a works council. On the other hand, 29.5 per cent of the plants in the West and 46 per cent of those in the East had neither a works council nor a collective agreement (Bellmann et al. 1998b). While both institutional pillars of the German industrial relations system are affected by the trend towards erosion, the decline in works council coverage has been more profound than the erosion of collective bargaining.

\section{Works Council Elections 1981-1994}

Since its first legal introduction in 1952, the system of plant-level codetermination has been subject to two major reforms. The first one dates 
from 1972 and has been the most important single factor for trade union membership recruitment ever since. Through this reform, trade unions got unrestricted access to companies and could initiate works council elections themselves. They could visit employees at their workplaces and did not need the consent of the employers any more when visiting plants. Works council members could participate in trade union seminars, and employers had to pay for the expertise of trade union experts in questions of work organization and new technology. With the reform of the Works Constitution Act in 1972, trade unions were firmly enshrined into the German system of workplace industrial relations.

Compared with the 1972 legislation, the reform by the conservative coalition government in 1989 was modest. Works councillors gained better consultation rights in the process of the introduction of new technology, and the employees affected by it had separate information rights. Vocational training was improved in order to ease the process of technological change. At the same time, the election modus of works councils was changed in favour of small groups. Previously, works council elections had been completely under the control of industrial trade unions. After smaller-interest organizations had complained at the German constitutional court, they had to be granted access to election procedures. Since the law was changed, every group in a company can put forward candidates and the number of signatures required for a proposal has been reduced. As a consequence, the monopoly position of the German DGB trade unions has been slightly reduced.

However, the continuing erosion of the German works council system does not stem from the change of law in 1989, but to a much greater extent from the shrinking base of companies in which works councils are being elected. The first works council election after unification in 1994 resulted in 38,425 plants with works councils and about 220,000 works council members (Table 2). During the 1980s, the number of plants with works councils decreased from 37,650 (in 1981) to 35,198 (in 1990) and the number of works councillors from 202,086 to 190,138 . Those 38,425 plants in which works councils were elected in 1994 employed about 9 million employees in the private sector; this is a coverage rate of 41.6 per cent in that sector.

The coverage rate by works councils in the private sector has decreased continuously during the 1980s. While the number of employees in plants with works councils has shrunk between 1981 and 1984 from 8.7 to 8.1 million employees and increased during the second half of the 1980s (from 8.2 million in 1987 to 8.3 million in 1990), the increase in the private sector as a whole has been more rapid than in those companies with works councils. As a consequence, the coverage rate shrank from 52.4 per cent in 1981 to 51.4 per cent in 1984 , to 49.9 per cent in 1987 down to 47.3 per cent in 1990. The most drastic decline occurred between 1990 and 1994, from 47.3 to 41.6 per cent. To some extent this sharp decrease in coverage is due to the problems of trade union organization after unification, which led to a

(C) Blackwell Publishers Ltd/London School of Economics 1999. 
TABLE 2

Employment and Works Council Election Results in the Private Sector, 1981-1994

\begin{tabular}{|c|c|c|c|c|c|}
\hline & 1981 & 1984 & 1987 & 1990 & 1994 \\
\hline No. of plants & 37,650 & 36,492 & 35,687 & 35,198 & 38,425 \\
\hline No. of works council seats & 202,086 & 192,277 & 190,201 & 190,138 & 203,041 \\
\hline $\begin{array}{l}\text { No. of employees in plants with } \\
\text { works councils ('000) }\end{array}$ & 8,748 & 8,106 & 8,227 & 8,327 & 9,022 \\
\hline $\begin{array}{l}\text { Total no. of employees in the } \\
\text { private sector ('000) }\end{array}$ & 17,290 & 16,410 & 17,179 & 18,324 & 22,839 \\
\hline $\begin{array}{l}\text { Share of no. of employees in plants } \\
\text { with works councils in total } \\
\text { employment in the private sector }\end{array}$ & 50.6 & 49.4 & 47.9 & 45.4 & 39.5 \\
\hline $\begin{array}{l}\text { Total employment (including } \\
\text { civil servants) ('000) }\end{array}$ & 23,242 & 22,472 & 23,528 & 24,838 & 30,778 \\
\hline $\begin{array}{l}\text { No. of employees in workplaces } \\
\text { without works councils }\end{array}$ & 8,543 & 8,305 & 8,952 & 9,998 & 13,817 \\
\hline $\begin{array}{l}\text { Share of employees in workplaces } \\
\text { without works councils in total } \\
\text { private-sector employment }\end{array}$ & 49.4 & 50.6 & 52.1 & 54.6 & 60.5 \\
\hline $\begin{array}{l}\text { Share of employees in workplaces } \\
\text { without works councils in } \\
\text { total employment }\end{array}$ & 36.8 & 37 & 38 & 40.3 & 44.9 \\
\hline
\end{tabular}

Notes on data collection: All data on works council elections were gathered as part of the research team of the Commission on Co-determination, a project funded by the Bertelsmann Foundation and the Hans-Böckler-Foundation and chaired by Wolfgang Streeck of the MaxPlanck-Institut für Gesellschaftsforschung. A summary of the data on plant-level and company-level trade union representation has been published in the Report of the Codetermination Commission, 1998.

Data on works council elections are based on the reports of DGB trade unions (IG Metall, IG Chemie, NGG, GTB, Leder, HBV BSE, IG Medien, GHK and ÖTV). In cases where trade union reports did not give any figures on employment, the figures are estimates based on the figures of those who were entitled to vote. In those cases where there were neither employment figures nor voters, employment was estimated on the basis of the works council mandates. Employment figures for trade union membership domains are based on the classification of the Statistisches Bundesamt: IG Metall: 23, 24, 25; IG Chemie: 20, 21, 22; NGG: 28/29; HBV: 4, 6; BSE: 3; IGBE: 1; ÖTV: 50 (not 0.7).

Sources: trade union annual reports, various issues; Statistical Yearbook for the Federal Republic of Germany of the Federal Office for Statistics, own calculations.

lower level of participation in works council elections in the eastern states, and also to problems with the statistical evaluation of the elections.

The more important explanation for the long-term decline in the coverage rate through works councils lies however in the tendency towards smaller company size and the structural shift in employment patterns. Results of company surveys that include questions on works council representation emphasize the fact that the likelihood of works council elections increases with the size of the company (Wassermann 1992; Addison et al. 1995). A survey on companies in the manufacturing sector in Lower Saxony (Hannoveraner Firmenpanel) concluded that a works council exists in less than 4.7 per cent of companies having 5-20 employees; 
in companies with 21-100 employees the share of companies with a works council increased to 45.5 per cent; in companies with more than 300 employees it stood at 97.2 per cent (Addison et al. 1995, 1998). ${ }^{4}$ In this sense, German unification again contributed to a decrease in works council coverage, since the average plant size in the eastern states is only between 50 and 70 per cent of the average plant size in the west (Rudolph and Wassermann 1996: 160).

Unfortunately, there is no statistical information on employment growth in small companies, since the workplace count of the Federal Statistical Office in Wiesbaden dates back to 1987 and has not been renewed since. At that time, there were already 3.5 million employees in plants with fewer than five employees. Those employees not only lack the right to elect a works council but also have fewer employment protection rights. Since the number of companies is increasing more rapidly than the number of employees, the indications suggest a decreasing average number of employees per plant.

The second important explanation for the declining coverage rate is the changing employment structure. The coverage rate of works councils varies greatly between sectors. In those sectors that statistically can be brought into accordance with the membership domain of trade unions, sectorspecific coverage rates can be calculated. In 1994, the coverage rate within the membership domain of the chemical trade union IG Chemie stood at 73 per cent, and that of the metal sector trade union IG Metall at 68 per cent. For the building sector trade union the coverage rate was 35 per cent and for the banking trade union $\mathrm{HBV}^{5}$, only 22 per cent (Table 3 ).

The decline in coverage rates has affected all sectors. Between 1981 and 1994 the coverage rate for the HBV decreased from 30 to 22 per cent; for the building sector trade union BSE from 43 to 35 per cent, for IG Metall from 77 to 68 per cent and for IG Chemie from 77 to 73 per cent. Therefore, changes in the employment structure have a double effect on works council coverage. Employment shares in those sectors that already have a low coverage are increasing, while the coverage rate itself in those sectors is shrinking more rapidly than in highly organized traditional manufacturing sectors. The low and decreasing coverage rate in private-service sectors therefore coincides with the relative increase in employment in these sectors.

Trade union density among works councillors has generally been high and stable throughout the 1980s and 1990s. ${ }^{6}$ According to trade union sources, the DGB trade unions have on average three-quarters of the works council mandates in their membership (Table 4). ${ }^{7}$ In the long run, changes in trade union density of works council mandates can be observed with regard to the white-collar trade union DAG and non-union members. The share of the DAG in works council elections has decreased gradually during the 1970s and 1980s, from 14.6 per cent in 1975 to 4.6 per cent in 1990 (Niedenhoff 1987, 1995). The share of works councillors who are not members of a union increased from 23.3 to 26.5 per cent between 1981 and

(C) Blackwell Publishers Ltd/London School of Economics 1999. 
TABLE 3

Results of Works Council Elections, 1981-1994

\begin{tabular}{|c|c|c|c|c|c|}
\hline Trade union & 1981 & 1984 & 1987 & 1990 & 1994 \\
\hline \multicolumn{6}{|l|}{ Metal sector (IG Metall) } \\
\hline No. of plants & 10,168 & 9,877 & 10,181 & 10,021 & 11,510 \\
\hline No. of employees (in thousand) & 3,756 & 3,428 & 3,618 & 3,712 & 3,489 \\
\hline $\begin{array}{l}\text { Share of total employment in } \\
\text { the domain of the IG Metall (\%) }\end{array}$ & 77 & 78 & 74 & 72 & 68 \\
\hline \multicolumn{6}{|c|}{ Chemical Sector and Ceramics (IG Chemie) } \\
\hline No. of plants & 3,216 & 3,224 & 3,221 & 3,359 & 4,231 \\
\hline No. of employees (in thousand) & 1,012 & 954 & 987 & 1,020 & 1,039 \\
\hline $\begin{array}{l}\text { Share of total employment in } \\
\text { the domain of the IG Chemie (\%) }\end{array}$ & 77 & 76 & 76 & 74 & 73 \\
\hline \multicolumn{6}{|l|}{ Food and restaurant sector (NGG) } \\
\hline No. of plants & 2,328 & 2,342 & 2,636 & 3,080 & 2,944 \\
\hline No. of employees (in thousand) & 408 & 387 & 419 & 506 & 458 \\
\hline \multicolumn{6}{|l|}{ Textile and clothing (GTB) } \\
\hline No. of plants & 2,699 & 2,445 & 2,280 & 2,180 & 1,953 \\
\hline No. of employees (in thousand) & 427 & 362 & 347 & 340 & 281 \\
\hline \multicolumn{6}{|l|}{ Leather (Gewerkschaft Leder) } \\
\hline No. of plants & 294 & 265 & 233 & 200 & 184 \\
\hline No. of employees (in thousand) & 69 & 62 & 58 & 50 & 43 \\
\hline \multicolumn{6}{|c|}{ Retailing, banking and insurance (HBV) } \\
\hline No. of plants & 6,107 & 5,918 & 6,181 & 5,840 & 5,361 \\
\hline No. of employees (in thousand) & 1,086 & 1,035 & 1,044 & 1,027 & 1,073 \\
\hline $\begin{array}{l}\text { Share of total employment } \\
\text { in the domain of the HBV (\%) }\end{array}$ & 30 & 29 & 29 & 26 & 22 \\
\hline \multicolumn{6}{|l|}{ Building sector (IG Bau-Steine-Erden) } \\
\hline No. of plants & 6,317 & 5,759 & 4,833 & 4,826 & 6,203 \\
\hline No. of employees (in thousand) & 724 & 654 & 591 & 614 & 828 \\
\hline $\begin{array}{l}\text { Share of total employment } \\
\text { in the domain of the BSE (\%) }\end{array}$ & 43 & 42 & 41 & 42 & 35 \\
\hline \multicolumn{6}{|l|}{ Media and Printing (IG Medien) } \\
\hline No. of plants & 2,069 & 2,029 & 2,036 & 2,049 & 1,901 \\
\hline No. of employees (in thousand) & 290 & 274 & 280 & 284 & 290 \\
\hline \multicolumn{6}{|l|}{ Wood and plastic manufacturing (GHK) } \\
\hline No. of plants & 1,814 & 1,671 & 1,516 & 1,590 & 1,555 \\
\hline No. of employees (in thousand) & 241 & 204 & 196 & 217 & 227 \\
\hline \multicolumn{6}{|c|}{ Mining and energy (IG Bergbau u. Energie) } \\
\hline No. of plants & 361 & 355 & 341 & 303 & 587 \\
\hline No. of employees (in thousand) & 278 & 264 & 263 & 218 & 308 \\
\hline $\begin{array}{l}\text { Share of total employment } \\
\text { in the domain of the IGBE (\%) }\end{array}$ & 57 & 56 & 56 & 49 & 57 \\
\hline \multicolumn{6}{|l|}{ Public sector and transport (ÖTV) } \\
\hline No. of plants & 2,277 & 2,607 & 2,229 & 1,750 & 1,996 \\
\hline No. of employees (in thousand) & 478 & 499 & 437 & 339 & 414 \\
\hline $\begin{array}{l}\text { Share of total employment } \\
\text { in the domain of the ÖTV (\%) }\end{array}$ & 77 & 81 & 65 & 44 & 42 \\
\hline
\end{tabular}

Notes on data collection: see Table 2.

Sources: trade union annual reports, various issues; Statistical Yearbook for the Federal Republic of Germany of the Federal Office for Statistics, own calculations. 
TABLE 4

Trade Union Density of Works Councillors, 1981-1994

\begin{tabular}{lcccc}
\hline & $\begin{array}{c}\text { No. of seats held by } \\
\text { DGB unions (\%) }\end{array}$ & $\begin{array}{c}\text { No. of seats held by } \\
\text { DAG }(\%)\end{array}$ & $\begin{array}{c}\text { No. of seats held by } \\
\text { other unions }\end{array}$ (\%) & $\begin{array}{c}\text { No. of seats held by } \\
\text { non-union members (\%) }\end{array}$ \\
\hline \multirow{2}{*}{1981} & 154,282 & 6,728 & 1,098 & 37,017 \\
& $(77.5)$ & $(3.4)$ & $(0.6)$ & $(18.6)$ \\
1984 & 147,184 & 5,703 & 1,068 & 36,238 \\
& $(77.4)$ & $(3.0)$ & $(0.6)$ & $(19.1)$ \\
1987 & 145,003 & 5,364 & 1,012 & 37,913 \\
& $(76.6)$ & $(2.8)$ & $(0.5)$ & $(20.0)$ \\
1990 & 140,091 & 4,711 & 937 & $(20.7)$ \\
& $(76.3)$ & $(2.6)$ & $(0.5)$ & 46,249 \\
$1994^{\text {a }}$ & 166,670 & 3,855 & 2,737 & $(20.1)$ \\
& $(75.2)$ & $(1.8)$ & $(1.2)$ & \\
\hline
\end{tabular}

${ }^{\text {a }}$ East and West Germany; private sector only.

${ }^{\mathrm{b}}$ Mainly the Christian Trade Union Confederation (CGB) and the Civil Servant Federation (DBB).

Notes on data collection: see Table 2.

Source: DGB.

1994 according to employers, and from 18.6 to 20.1 per cent according to the DGB (Table 4 and Niedenhoff 1995). The increase of non-union members in works councils is also sector-specific. Their rise is faster in those sectors in which the union density rate is already low and slower in those sectors in which trade unions are traditionally stronger (Table 5).

This leaves a growing segment of employees who work in companies without any form of plant-level co-determination. These are predominantly small and medium-sized companies and companies in the private-service

TABLE 5

Sectoral Breakdown of Unionization Rates of Works Council Members, 1994 (\%)

\begin{tabular}{lcccc}
\hline Trade union & DGB share & DAG share & Others $^{a}$ & Non-union $^{\text {D }}$ \\
\hline Leather & 77.9 & 0.01 & - & 21.0 \\
Insurance, Banking, Retailing & 54.2 & 7.4 & 0.6 & 32.5 \\
Education and Science & 47.7 & 1.5 & - & 38.9 \\
Media & 89.7 & - & 3.1 & 26.6 \\
Wood/Plastic & 82.4 & - & - & 17.3 \\
Textile & 80.8 & 0.5 & - & 18.7 \\
Chemical & 84.7 & 0.6 & - & 14.4 \\
Public Sector/Transport & 74.3 & - & 0.7 & 21.8 \\
Food/Restaurants & 91.2 & - & - & 8.3 \\
Metal & 81.1 & 1.3 & 0.4 & 17.3 \\
Forestry/Agriculture & 64.0 & - & - & 27.8 \\
Building Workers & 67.6 & 0.3 & - & 32.0 \\
Railway & 79.8 & - & 18.5 & 1.7 \\
Mining & 91.8 & 0.6 & - & 7.3 \\
\hline
\end{tabular}

${ }^{a}$ Mainly the Christian Trade Union Confederation (CGB) and the Civil Servant Federation (DBB).

Notes: see Table 4.

Source: DGB, 1994; own calculations, private sector only.

(C) Blackwell Publishers Ltd/London School of Economics 1999. 
sector, in which works councils are not set up although the legal conditions are fulfilled. In nominal figures, the number of those employees in the private sector who are not covered by plant-level co-determination has increased from 8.6 million in 1981 to 13.8 million in 1994. As a share of overall employment, the segment without co-determination stood in 1994 at 50 per cent compared with 41 per cent in $1984 .{ }^{8}$ In the private sector alone, the segment without co-determination stood at 62.6 per cent in 1994 compared with 49.4 per cent in 1981. In other words, almost two-thirds of all employees in the private sector currently do not have any access to plant-level consultation procedures.

\section{Collective Bargaining}

Traditionally, the coverage of collective bargaining in Germany has been extensive and has not permitted the emergence of a major non-union sector, as occurred in Anglo-Saxon countries. As of the end of 1995, there were still collective agreements for almost all economic sectors and companies, in which about 90 per cent of all employees are employed.

However, there are some indicators that hint at underlying changes within the collective bargaining system. First, the number of agreements that were declared legally binding by the Ministry of Labour increased during the 1980s (BMA 1998). At the same time, the percentage of whitecollar workers not covered by an agreement (because they are too high up in the management ladder) rose. In other words, the coverage of workers by collective agreements is increasingly shifting to the low-paid workers, while at the upper end white-collar workers are increasingly moving out of coverage.

A second feature of structural change in the collective bargaining system has been the steady increase of company agreements in relation to central collective agreements (Table 6). Between 1990 and 1997, the number of company agreements rose from 2100 to 3300 in west Germany and from 2700 to 5000 agreements for the whole of Germany. In percentage terms, this was an increase from 26 to 33 per cent in west Germany and from 27 to 35 per cent for the whole of Germany. In eastern Germany collective bargaining started off with a high number of company agreements, which then decreased over time. However, the continuous increase of company agreements in the west indicates a much more serious tendency towards fragmentation of the previously highly centralized collective bargaining system. Some of these company agreements developed from the privatization of public utilities, for example the German railway company (Deutsche Bundesbahn) and the German telecommunications company (Deutsche Telekom); in other cases, such as IBM, the company resigned from the employers' confederation and concluded a more favourable company agreement instead. 
TABLE 6

Collective Agreements in Germany, 1989-1997

\begin{tabular}{lllllll}
\hline & \multicolumn{5}{c}{ Company agreements as a share of total agreements } \\
\cline { 2 - 7 } & W. Germany & \multicolumn{2}{c}{ E. Germany } & Total & \\
& No. & $\%$ & No. & $\%$ & No. & $\%$ \\
\hline 1989 & 32,000 & 25 & - & - & 32,000 & 25 \\
1990 & 33,449 & 26 & 670 & 64 & 34,119 & 27 \\
1991 & 35,295 & 28 & 2,372 & 64 & 37,667 & 30 \\
1992 & 36,123 & 28 & 3,368 & 49 & 39,491 & 30 \\
1993 & 37,179 & 29 & 4,548 & 48 & 41,727 & 31 \\
1994 & 37,933 & 30 & 5,233 & 48 & 43,166 & 32 \\
1995 & 37,747 & 32 & 5,891 & 49 & 43,638 & 34 \\
1996 & 38,508 & 32 & 6,640 & 47 & 45,148 & 34 \\
1997 & 40,066 & 33 & 7,268 & 46 & 47,334 & 35 \\
\hline
\end{tabular}

Sources: Federal Ministry for Labour and Social Affairs, 1998; EIRO (1998b).

Since central collective agreements are concluded by employers' confederations on behalf of all member companies, the increase in company agreements is closely linked to the decrease in membership rates of employers' confederations. The third indicator for changes in the collective bargaining system is therefore the steady membership loss of employers' confederations. They have been losing members since the mid-1980s, with the pace of decline accelerating after 1990. Between 1985 and 1990 membership density of the metal confederation Gesamtmetall decreased from 54.6 to 46.5 per cent of the metal sector companies covering 73.8 and 70.3 per cent, respectively, of all employees in the sector (see Table 7). The underlying cause of the decline in employers' density in the west was not a wave of resignations from the associations, but a drastic increase of new companies being set up from the late 1980s onwards which did not join the employers' associations. Between 1985 and 1992, the number of companies in the metal industry increased from 15,333 to 18,348 in western Germany (Schroeder 1996).

TABLE 7

Density of Membership of the Metal Employers' Confederation Gesamtmetall, 1970-1993

\begin{tabular}{lccccc}
\hline & \multicolumn{2}{c}{ Companies } & & \multicolumn{2}{c}{ Employees } \\
\cline { 2 - 3 } & No. & Density $(\%)$ & & No. & Density (\%) \\
\hline 1970 & 9,594 & - & & $3,264,598$ & 73.3 \\
1980 & 9,108 & 57.5 & & $2,950,325$ & 72.7 \\
1985 & 8,374 & 54.6 & & $2,817,186$ & 73.8 \\
1989 & 8,116 & 46.5 & & $2,890,687$ & 70.3 \\
1993 & 8,863 & 42.8 & & $2,663,123$ & 63.1 \\
1993 west & 7,752 & 44.0 & & $2,458,665$ & 63.3 \\
1993 east & 1,111 & 35.7 & & 204,458 & 60.0 \\
\hline
\end{tabular}

Sources: Gesamtmetall; Statistical Yearbook for the Federal Republic of Germany of the Federal Office for Statistics, own calculations. 
The phenomenon of a general increase in the number of companies can be observed across sectors. To some extent this is due to the setting up of new companies in the information technology industry and the service sector, but to a great extent it is due to the restructuring of traditional companies. For example, in the banking sector, where more than 90 per cent of the employees still work for employers that are members of the banking employers' confederations, we can observe that subsidiaries such as 'direct banking' operations are set up by big banks. The subsidiaries do not join the employers' confederations but employ students or unskilled employees and pay below the going rate.

Whereas unification brought a temporary amelioration of the trade unions' membership problem, it made little difference to the employers' confederations, whose decline simply continued. Between 1990 and 1995 the density of the employers' organization Gesamtmetall decreased from 70 to 63 per cent of all metal sector employees. After 1989 regional employers' confederations were rapidly set up in the east, mainly by western managers with the support of the Treuhandanstalt (Henneberger 1993; Ettl and Heikenroth 1996). As early as 1990, the first regional metal employers' associations were founded in Thuringia and Saxony. However, with the exception of a few small companies, there was no private capital in the former East Germany, so it was much more difficult to build up employers' confederations there. Nevertheless, the western employers' federations tried to transfer their institutional structure to the east, but to this day the east German employers' organizations are much more fragmented. The level of organization of east German companies is still substantially lower than in the west, varying between 75 per cent in the chemical industry to around 35 per cent in the metal industry (Artus 1996). In the latter case, the proportion of companies that are members of an employers' confederation declined from 60 per cent in 1992 to 35 per cent in 1994. While most of the big companies still belong to an employers' federation, most of the newly established small and medium-sized companies do not (Schroeder 1996).

Survey data covering the years 1995 and 1997 confirm both the increasingly uneven structure and the structural changes in the collective bargaining system. They show that the percentage of employees in western Germany who are covered by collective agreements has decreased from 83.1 per cent in 1995 to 75 per cent in 1998 (Kohaut and Bellmann 1997: 326; Bellmann et al. 1998b). The same survey indicates the relatively weaker coverage of collective agreements in smaller companies: while in about a third of companies with 5-19 employees no collective agreement applies, the ratio decreases to less than 10 per cent in companies with 200 and more employees (Table 8). And while on average 38.4 per cent of western German companies were not subject to a collective agreement in 1995, non-coverage was particularly high in expanding sectors such as insurance (50.6 per cent) and other services (51.2 per cent) (Kohaut and Bellmann 1997: 324). 
TABLE 8

Coverage of Plants by Collective Agreements by Plant Size, 1995

\begin{tabular}{lccc}
\hline No. of employees & Sectoral agreement & Company agreement & No agreement \\
\hline $1-4$ & 37.6 & 7.5 & 54.8 \\
$5-9$ & 61.6 & 9.3 & 29.1 \\
$10-19$ & 60.6 & 7.2 & 32.2 \\
$20-49$ & 71.0 & 7.5 & 21.5 \\
$50-99$ & 78.6 & 7.9 & 13.5 \\
$100-199$ & 73.2 & 15.5 & 5.3 \\
$200-499$ & 80.3 & 13.8 & 8.2 \\
$500-999$ & 80.3 & 11.5 & 4.6 \\
$1000-4999$ & 79.0 & 16.3 & 0.0 \\
$5000+$ & 89.6 & 10.4 & 38.4 \\
Total & 53.4 & 8.2 & \\
\hline
\end{tabular}

Source: Kohaut and Bellmann (1997: 323).

\section{The pressure towards decentralization}

The decline in coverage by German industrial relations institutions has coincided with an increasing pressure towards greater decentralization in collective bargaining. These pressures can be observed both at the level of collective bargaining and through deregulations in company and plantspecific agreements.

On the level of collective bargaining, increasing efforts have been made by trade unions and employers to 'open up' agreements. 'Opening clauses' (Öffnungsklauseln) in central collective agreements empower plant-level actors to negotiate about issues that are generally dealt with by the central collective agreement. Given the presence of a two-layer system with collective bargaining on the associational level and works councils at the plant level, there is some scope for delegating the regulation of terms and conditions from the level of collective bargaining to individual companies. The collective bargaining partners can delegate issues to the plant level, but if they do not do that the plant-level actors cannot circumvent collective agreements. ${ }^{9}$ If the collective bargaining partners want to delegate an issue to the plant level, they have to state this explicitly in the collective agreements and to describe the limits of plant-level solutions. This form of delegation from collective agreements to plant agreements can be called 'regulated decentralization', since it indicates that the collective bargaining actors ask the plant-level actors to find a plant-specific solution to a problem which they do not want to regulate at a central level (Hassel and Schulten 1998). This form of regulated decentralization has been used in several ways.

\section{Opening Clauses for Working-time Arrangements}

The metal sector collective agreement of 1984 maintained that, not only

(C) Blackwell Publishers Ltd/London School of Economics 1999. 
could a group of workers be exempted from the working-time reduction, but also the distribution of working time could vary between companies. In order to allow for company-specific solutions, the agreement had an 'opening clause' which allowed for plant-level negotiations on the distribution of working time. Over the years, this has led to a rather flexible use of working time which nowadays allows for annual working time schemes in which workers might work 45 hours per week in summer but only 30 hours per week in winter or to be even more varied, depending on the order books of the company. The decision on how to distribute working time rests with the plant-level actors.

\section{Working-time Reduction without Compensation in Pay}

The collective agreement on employment security settled in the metal sector during the 1994 bargaining round entails provisions for individual companies to vary the standard working time for their employees rather than make them redundant. If an employer runs into economic difficulties, he or she can cut working time down to 30 hours for a certain period of time in order to reduce labour costs. The decision to cut working time and pay can be taken by the employer and the works council. According to a survey commissioned by Gesamtmetall in September 1994, about 10 per cent of those companies that replied to the questionnaire, employing 16 per cent of all employees covered by the survey, had made use of the provisions. Gesamtmetall estimated at the time that, on average, working time had been reduced by 10 per cent, saving up to 50,000 jobs in the industry.

\section{Hardship and Exemption Clauses}

The so-called hardship clauses were introduced in collective agreements in the manufacturing sector in east Germany. They enable eastern companies to apply to be exempted from the collective agreement if they are close to bankruptcy. The company is asked to demonstrate that it has a strategy for economic viability, and the collective bargaining partners can then decide whether the company should be exempted from paying the agreed rates for their employees. If no agreement is arrived at between the collective bargaining partners, the original collective agreement is upheld. ${ }^{10}$ This was the first serious step towards decentralizing the German collective bargaining system, since it took into account the differentiation between companies as a recognized issue; but in practice the tool was much less used that anticipated. ${ }^{11}$

Since 1996, collective agreements have also increasingly included other variations of standardized working conditions under certain circumstances. Exemptions from the minimum wage have been made for certain groups such as the long-term unemployed and for certain types of company such as medium-sized ones. Also, certain types of terms and conditions such as bonuses and working time were lowered across the board (Bispinck 1997). 


\section{Company-specific Agreements}

More recently, there have been examples of company agreements in service departments or subsidiaries of big manufacturing companies which have deviated from sectoral agreements. In the service subsidiary of the Daimler Benz AG, the metal sector trade union IG Metall concluded a supplementary agreement in March 1998 which provides for longer working time and less regulation of work organization in order to prevent those companies from evading any form of collective agreement. This is the first agreement that allows for a major differentiation in terms and conditions within the same sector and even within the same company (EIRO 1998a).

These examples show how the collective bargaining actors have tried to pre-empt pressures to decentralize collective bargaining by allowing for some differentiation but at the same time carefully avoiding delegating decision-making rights to the plant level, which would include decisions on the going rate for a particular job. Instead, they have been more generous with the distribution and the reduction of working time at a standard hourly rate. Where companies are enabled to cut hourly pay - as in the East German example - the final decision-making right still rests with the collective associations.

In addition to existing forms of flexibility within the collective bargaining system, employers' confederations have tried to go further. For example, in June 1996 and again in December 1997, Gesamtmetall presented reform proposals for collective bargaining in the metal sector. It proposed dividing regional collective agreements into two parts: one with a small range of minimum standards for all member companies, and a second with optional regulations which could be adopted by member companies but would not be obligatory. The first category includes wage increases, the level of standard wages, the overall working time, holidays, bonuses, notice periods for layoffs and arbitration procedures. The second part should entail either framework regulations or recommendations, involving different options which could be chosen by companies. Gesamtmetall also suggested the introduction of a general clause in collective agreements which would enable both sides to replace parts of the collective agreement by plant agreements. However, these further initiatives have been blocked by the functional division of labour between works council and collective bargaining, which does not allow for a transfer of collective bargaining rights to the works council.

On the level of individual companies and plants, there have been attempts to free companies from the regulatory framework through arrangements in which management and works councils can come to agreements outside the official collective bargaining agenda. These companies might still belong to the employers' confederation, but nevertheless might choose to opt out of collective agreements and, either openly or

(C) Blackwell Publishers Ltd/London School of Economics 1999. 
secretly, make agreements with their work-forces or works councils for doing so.

Deviation of individual companies from regulation by collective agreements has been observed in both western and eastern Germany. In the west, companies tend to require longer working hours from their employees for the same pay, since cuts in pay are not readily accepted. In a survey organized by the Association of Medium-sized Companies (VMU), a third of the companies stated that they do not strictly follow the collective agreement - mainly regarding working-time arrangements. In the east, managements have frequently asked their employees to accept lower pay than that laid down in the collective agreement. A recent survey of manufacturing companies showed that, in the category of companies with 500-1000 employees, though all were members of the employers' association and subject to its collective agreements, only 78 per cent were paying the going rate (Ettl and Heikenroth 1996: 150). ${ }^{12}$

In some cases these forms of plant-level deviation from standard terms and conditions were rather secret, while in other cases they took the form of open alliances between management and works councils against the collective bargaining parties. In recent years there have been a number of companies that openly and deliberately forged agreements with their workforces in which employees were asked to accept concessions in exchange for guaranteed employment security for a number of years.

These plant agreements - often labelled as 'pacts' for safeguarding production sites - vary considerably in form and scope. With regard to their impact on the decentralization process of German collective bargaining, however, there is a major difference between them with regard to the extent to which they remain within the framework of existing collective agreements or go beyond them. In big manufacturing companies such as Opel, Ford, Bayer, Continental and Hoechst Marion Roussel (HMR), costcutting bargains have been struck between management and the works council. Management has agreed to make detailed investment and job guarantees as well as improve training facilities and employment security for trainees; in exchange, the works council has conceded to measures to lower labour costs through the removal of special bonuses, the flexibilization of working time and other manpower flexibility measures. These bargains have usually taken the form of plant agreements and have been accepted by the unionized works council and the unions themselves. With regard to the scope of pay cuts and flexibility measures, these agreements generally have not affected wage rates as laid down in collective agreements, but rather bonuses above the going rate. However, the precondition for these bargains has been that companies were already paying above the basic wage rates laid down in collective agreements and therefore were able to cut the additional voluntary part of pay.

There have also been a number of cases - predominantly in mediumsized companies, such as the radiator manufacturer Viessmann and the game producer Ravensburger — in which management has asked the work- 
force more or less openly to violate the existing collective agreement. In these cases each employee has had to sign a new individual contract in which he or she has accepted that parts of the existing collective agreement were void. These agreements have generally asked employees to accept an increase in unpaid working time of up to 3 hours per week and lower overtime bonuses; in exchange, the company has generally promised that no jobs would be located to other production sites and that no mass redundancies would occur.

The dynamics of decentralization leads to very different outcomes in individual companies depending on the degree of influence of the collective bargaining associations on the plant-level bargaining process. Some collective bargaining actors have started to delegate issues to the plant level in order to pre-empt increasing pressure from below. By regulating a process of decentralization from above, they have tried to ensure that plant-level developments can be maintained within the collective bargaining system. These are companies that tend to have a unionized works council and a closer relationship to trade unions and employers' confederations and do not want to upset the collective bargaining system as a whole.

In the case of companies that did not have the possibility of cutting voluntary bonuses or downgrading a pay structure above the collectively agreed wage, decentralization has not remained within the framework of collective agreements, but has taken the form of substitution. Rather than take up issues that had been delegated from the central level to the plant level, management has opened an independent collective bargaining agenda from below. Violations of existing agreements have usually been based on unilateral managerial decisions and not on consultation with the works council.

Three observations emerge from these two processes of decentralization, i.e. from above and from below. First, the attempt of collective bargaining actors to open agreements has not succeeded in pre-empting pressures from below. Since collective agreements are always both straitjackets and peace-keeping devices, the introduction of plant-level decision-making rights into existing agreements might introduce little flexibility for management. Indeed, since management usually has to negotiate with its work-force on the introduction of flexibility measures, the delegation from central collective agreements might actually generate plant-level conflict. Therefore, opening clauses in collective agreements might not help plant-level actors to develop new forms of flexible work organizations.

Second, plant-level concession bargaining within existing collective agreements as is practised by big manufacturing companies might increase the pressure on medium-sized companies to violate existing agreements. Big companies have been able to cut voluntary bonuses and have increasingly used this tool for cost-cutting. This form of concession bargaining within big manufacturing companies distorts the precarious balance of labour costs in respect to other companies in the same sector and

(C) Blackwell Publishers Ltd/London School of Economics 1999. 
alters their relative competitive position. As a result, wages are squeezed and no longer reflect the relative competitive position between companies. Smaller companies which do not pay voluntary bonuses are forced to adjust their own labour costs accordingly and thereby to find more drastic solutions for doing so. The irony is that, while the big manufacturing companies remain the main pillar of the German collective bargaining system, their downward adjustment of wages to the level of the collectively agreed wage might at the same time lay the ground for a more substantial process of driving medium-sized companies out of the collective bargaining system altogether.

Third, in those cases where terms and conditions were undercut in violation of the existing collective agreements, the works council often played a crucial role. In the case of Viessmann, the works council was nonunion and from the start stood in opposition to union protests. At IBM, the management was able to exploit the divisions between the works council majority, which was IG Metall, and the minority, which belonged to the white-collar union DAG. The DAG works councillors were then prepared to sign a company agreement including longer working time. Non-union works councillors are more readily prepared to form productivity coalitions with management by accepting working conditions that are unacceptable to trade unions (Windolf 1996). On the other hand, one can argue that it is the linkage between trade unions and works councils that is a crucial stabilizing factor for collective bargaining, since it prevents plant-level decisions that violate collective agreements.

\section{Conclusion: the dynamics of decentralization and institutional erosion}

In the traditional German model of industrial relations, the structure of encompassing industrial trade unionism was the unifying force binding together the centrifugal tendencies of plant-level self-interest of works council action and macroeconomic steering functions of the collective bargaining system. Works councils were able to feed trade unions with members and to supervise the implementation of central agreements. Trade unions assisted works councils in their local bargaining function and integrated powerful works councillors into their organizations. Under today's economic conditions, the mutually supportive functions of the model are being subjected to a downward spiral of decentralization pressures and institutional erosion.

The decreasing coverage of works councils in the private sector undermines the traditional recruitment mechanisms of German trade unions. German trade unions have remained strong in those areas where they have been traditionally strong; but are not gaining members in those areas where they have been traditionally weak.

The relatively smaller coverage of works councils in the private sector has until recently been compensated by the high coverage of collective

(C) Blackwell Publishers Ltd/London School of Economics 1999. 
agreements. Even where works councils did not exist, collective agreements provided a stable framework for terms and conditions. A parallel decline in works council and collective bargaining coverage, however, leads to a shrinking regulative capacity of the German industrial relations institutions. As a result, the established institutions will continue to provide a frame of reference, but for a decreasing share of employees.

All three major aspects of the German industrial relations system co-determination, collective agreements and encompassing interest associations - are therefore facing the same problems of decreasing coverage and confinement to a traditional segment of the labour market. They are concentrated on large companies in manufacturing, which represent the backbone of the German model. Here we find stable trade union density rates, and high coverage rates of collective bargaining and works councils. ${ }^{13}$ Here we also find patterns of concession bargaining which try to remain within the German industrial relations system by confining pay cuts to voluntary bonuses. All three institutional pillars are similarly weak in the expanding parts of the economy, which are predominantly in the service sector. This fact supports the proposition that there is a complementary and systemic relationship between co-determination and collective bargaining which is supported by strong encompassing associations. To the extent that plant-level co-determination erodes, the efficiency of central collective bargaining will be less able to perform its regulative and distributive tasks on the labour market.

This interconnection also shows the limits of further decentralization of the collective bargaining system: a transfer of collective bargaining functions from the collective bargaining arena to the plant level — as envisaged by employers' confederations - is viable only where works councils are actually in place. In cases where works councils are weak or absent, it will lead to a new constellation of the different levels of interest representation in which the division of labour will become more blurred. Plant-level and sectoral-level collective bargaining will coincide, and there will be an increasing share of companies that are neither members of employers' confederations nor covered by works councils. In this situation, a further process of decentralization will add to the existing tendency of fragmentation and will not be a mere continuation of existing bargaining arrangements at the plant level.

One consequence of the ongoing process of decentralization is that the balance between co-operative plant-level industrial relations and more conflictual sectoral collective bargaining relations will be disturbed. In particular, works councils, which will have an increased role in the bargaining process, will tend to be more sectionalist. While this might add to the tendency towards productivity coalitions in economically difficult times (Windolf 1996), it will also add to more plant-specific and less comprehensive demands during economic upswings. In any case, if works councils formally enter collective bargaining arrangements, there will be

(C) Blackwell Publishers Ltd/London School of Economics 1999. 
strong pressures to lift the ban on industrial action in workplace industrial relations.

Decentralization also adds to the growing gap between highly regulated sectors with strong industrial relations institutions and poorly regulated sectors with weak institutions. These differences are both sector-specific and firm-size-specific, since small companies are less likely to participate in collective bargaining or to have a works council. A growing regulation gap between big and small companies will exacerbate the already conflictual relationships between companies of different sizes within employers' confederations and increase the problem of collective action of employers' confederations even further. While this process of institutional erosion might take a long time, in the end, the German model of industrial relations will more and more lose its exclusivity and distinctiveness.

Final version accepted 29 October 1998.

\section{Notes}

1. This system of wage determination was particularly important during the $1950 \mathrm{~s}$ and 1960s, under conditions of high growth rates and full employment, in order to control the general development of wages. Indeed, until the mid-1970s wages in Germany rose in line with the general growth rates of the economy.

2. For the general features of the so-called dual system of interest representation, see Jacobi et al. (1992); Schnabel (1995); Visser and van Ruysseveldt (1996).

3. Getting statistical data on the wage gap differential between collectively agreed and effective wages is not easy, since studies are rare. One study that looked at the differential has shown that the wage gap narrowed between 1973 and 1992. While in 1973 average real wages were 12.7 per cent higher than collective agreement wages, in 1992 the gap was only 7.9 per cent (Schnabel 1994: 41). A more recent study drawing from the IAB establishment panel found a wage gap of 11.4 per cent for 1997 (Bellmann et al. 1998a).

4. The survey by Wolfram Wassermann has similar results. Only 13 per cent of the companies with 5-20 employees have a works council, and only 34 per cent of those companies with 21-50 employees (Wassermann 1992: 29).

5. In the private-service sector there are works councils that are covered not by the banking trade union HBV, but by the white-collar trade union DAG or by nonunion members. For statistical reasons, these works councils are not taken into account in this figure.

6. Therefore, the elections in 1990 and 1994 show that the reform of the Works Constitution Act has not led to an increase in smaller trade unions at the expense of the DGB: on the contrary, the DGB trade unions were able to increase their share.

7. According to the employers' based research institute, Institut der deutschen Wirtschaft, the share of the DGB trade unions stands at about two-thirds of all seats (Niedenhoff 1987).

8. This calculation is based on the assumption that works councils are present throughout the public sector. 
9. This refers mainly to pay and working time. On issues where the collective agreement does not provide any regulation, the companies are free to find their own devices, e.g. regarding work organization and teamwork.

10. For details on the process, see Koch (1995: 145f.).

11. The IG Metall was not prepared to accept that any company belonging to the Treuhandanstalt was in hardship, and many other companies in any case did not want to open their order books to the trade union (Henneberger 1993).

12. In the category of 1000-5000 employees, the relative shares were exactly reversed.

13. Here we also find a high — and increasing — level of trade union representation in company-level co-determination (Kommission Mitbestimmung 1998).

\section{References}

Addison, J. T., Schnabel, C. et al. (1995). 'On the determinants of "mandatory" works councils in Germany'. Discussion Paper, University of Lüneburg.

—_ (1998). Works Councils in Germany: Their Effects on Firm Performance. Lüneburg: University of Lüneburg Press.

Artus, I. (1996). Die Etablierung der Arbeitgeberverbände und die Tarifgestaltungspraxis in Ostdeutschland. Jena: Friedrich-Schiller-Universität Jena, Forschungsbericht im Auftrag der Hans-Böckler-Stiftung.

Bellmann, L., Kohaut, S. and Schnabel, C. (1998a). 'Ausmass und Entwicklung der übertariflichen Entlohnung'. IW-Trends, 2: 5-14.

Bellmann, L., Ellguth, P. and Seifert, H. (1998b). 'Betriebsräte und Tarifpolitik: Quantitative Reichweite der Mitbestimmung'. Unpublished paper, Institute for Employment Research, Nuremburg.

Bispinck, R. (1997). 'Deregulierung, Differenzierung und Dezentralisierung des Flächentarifvertrags: Eine Bestandsaufnahme neuerer Entwicklungstendenzen der Tarifpolitik'. WSI-Mitteilungen, 8: 551-61.

BMA (1998). Tarifvertragliche Arbeitsbedingungen im Jahre 1997. Bonn: BMA.

EIRO (1998a). Debis AG Agreement: A First in Industry-related Services. Dublin: Dublin Foundation for the Improvement of Living and Working Conditions.

- (1998b). Company-level Bargaining Gains Importance. Dublin: Dublin Foundation for the Improvement of Living and Working Conditions.

Ettl, W. and Heikenroth, A. (1996). 'Strukturwandel, Verbandsabstinenz, Tarifflucht: Zur Lage der Unternehmen und Arbeitgeberverbände im ostdeutschen verarbeitenden Gewerbe'. Industrielle Beziehungen, 3(2): 134-50.

Hassel, A. and Schulten, T. (1998). 'Globalisation and the future of central collective bargaining: the example of the German metal industry'. Economy and Society, 27: 527-41.

Henneberger, F. (1993). 'Transferstart: Organisationsdynamik und Strukturkonservatismus westdeutscher Unternehmerverbände - Aktuelle Entwicklungen unter besonderer Berücksichtigung des Aufbauprozesses in Sachsen und Thüringen'. Politische Vierteljahresschrift, 34: 640-73.

Jacobi, O., Keller, B. and Müller-Jentsch, W. et al. (1992). 'Germany: Codetermining the Future'. In A. Ferner and R. Hyman (eds.), Industrial Relations in the New Europe. Oxford, Blackwell, pp. 218-69.

(C) Blackwell Publishers Ltd/London School of Economics 1999. 
Koch, K. (1995). 'The German Works Council and collective bargaining development since unification'. German Politics, 4(3): 145-55.

Kohaut, S. and Bellmann, L. (1997). 'Betriebliche Determinanten der Tarifbindung: Eine empirische Analyse auf der Basis des IAB-Betriebspanels 1995'. Industrielle Beziehungen, 4: 317-34.

Kommission Mitbestimmung (1998). Mitbestimmung und neue Unternehmenskulturen. Bilanz und Perspektiven. Gütersloh: Verlag Bertelsmann Stiftung.

Niedenhoff, U. (1987). Die Betriebsratswahlen: Die Betriebsräte bis 1990. Cologne: Deutscher Instituts-Verlag.

— (1995). Betriebsrats- und Sprecherausschusswahlen 1994. Cologne: Deutscher Instituts-Verlag.

Rudolph, W. and Wassermann, W. (1996). Betriebsräte im Wandel: Aktuelle Entwicklungsprobleme gewerkschaftlicher Betriebspolitik im Spiegel der Betriebsratswahlen. Münster: Verlag Westfälisches Dampfboot.

Schnabel, C. (1994). Die übertarifliche Bezahlung. Cologne: Deutscher InstitutsVerlag.

- (1995). 'Entwicklungstendenzen der Arbeitsbeziehungen in der Bundesrepublik Deutschland seit Beginn der achtziger Jahre: Eine Analyse unter besonderer Berücksichtigung der Arbeitgeberseite'. In M. Mesch (ed.), Sozialpartnerschaft und Arbeitsbeziehungen in Europa. Vienna: Manz, pp. 53-74.

Schroeder, W. (1996). 'Gewerkschaften und Arbeitgeberverbände'. Gewerkschaftliche Monatshefte, 47: 601-21.

Streeck, W. (1984a). 'Qualitative demands and the neo-corporatist manageability of industrial relations'. British Journal of Industrial Relations, 19: 149-69.

— (1984b). 'Co-determination: the fourth decade'. In B. Wilpert and A. Sorge (eds.), International Yearbook of Organizational Democracy, Vol. 2, International Perspectives on Organizational Democracy. Chichester: John Wiley, pp. 391-422.

Thelen, K. (1991). Union of Parts: Labor Politics in Postwar Germany. Ithaca, NY: Cornell University Press.

— and Turner, L. (1997). German Codetermination in Comparative Perspective. Gütersloh: Verlag Bertelsmann Stiftung.

Visser, J. and van Ruysseveldt, J. (1996). Robust Corporatism, Still? Industrial Relations in Germany. In J. van Ruysseveldt and J. Visser (eds.), Industrial Relations in Europe: Traditions and Transitions. London: Sage.

Wassermann, W. (1992). Arbeiten im Kleinbetrieb: Interessenvertretung im deutschen Alltag. Cologne: HBS Praxis, Bund-Verlag.

Windolf, P. (1996). Productivity Coalitions and the Future of Unionism. In B. Marin (ed.), Governance and Generalized Exchange: Self-Organizing Policy Networks in Action. Frankfurt: Campus/Westview, pp. 289-314. 